\title{
THERMODYNAMIC PROPERTIES OF TAMARIND SEEDS (Tamarindus indica L.)
}

\author{
Weder N. Ferreira Junior ${ }^{1 *}$, Osvaldo Resende ${ }^{1}$, Ligia C. de M. Silva1, \\ Gleyce K. I. Pinheiro ${ }^{1}$, Kelly A. de Sousa ${ }^{1}$
}

${ }^{1 *}$ Corresponding author. Instituto Federal de Educação, Ciência e Tecnologia Goiano - Campus Rio Verde/ Rio Verde - GO Brasil.
E-mail: wedernunesiftm@ @mail.com | ORCID ID: https://orcid.org/0000-0002-2931-9352

\section{KEYWORDS}

equilibrium moisture content, enthalpy, Gibbs free energy.

\begin{abstract}
Tamarind is used in the food and pharmaceutical industry, and its seed is the main means for the reproduction of this species, thus justifying studies that ensure its post-harvest viability. This research aimed to study the thermodynamic properties of tamarind seeds as a function of the equilibrium moisture content. The experimental data of the water activities were obtained by the indirect static method. The Cavalcanti Mata model was used to determine the thermodynamic properties of tamarind seeds, as it was the model that best fitted the experimental data of the desorption isotherms. The results showed that the thermodynamic properties are influenced by the moisture content and temperature, with an increase in the energy required to remove water from the product with a decrease in moisture content. The net isosteric heat of desorption increases with a reduction of moisture content ranging from $2,618.85$ to $2,510.25 \mathrm{~kJ} \mathrm{~kg}^{-1}$ for the moisture content range of 10.52 to $21.10 \% \mathrm{db}$. The latent heat of vaporization, the differential enthalpy, and the Gibbs free energy increase with a reduction of the moisture content of tamarind seeds.
\end{abstract}

\section{INTRODUCTION}

Tamarind seeds have a well-defined coat region, being irregular, rectangular, and rough, with a bright dark brown color and about $1.5 \mathrm{~cm}$ long and $1.2 \mathrm{~cm}$ wide (Sousa et al., 2010). Tamarind is used in the food and pharmacological industry, and its seeds, as well as those from woody fruit trees, are the main means for the reproduction of most of this species (Oliveira et al., 2006), thus requiring studies that ensure its post-harvest viability.

Drying stands out among the most used processes for maintaining the quality of plant products after harvest, as it is an indispensable technique for the quality control of plant products (Oliveira et al., 2011). The knowledge of this moisture content reduction process, which simultaneously involves the transfer of heat and mass, is essential for an efficient drying at technical and economic levels (Resende et al., 2011).

Thermodynamic properties aim to understand the water properties and calculate the energy demands associated with heat and mass transfer in biological systems (Cladera-Oliveira et al., 2008). Moreover, the study of these properties is essential in the analysis of projection and the dimensioning of equipment in various processes of product preservation and calculate the energy required in these processes (Corrêa et al., 2010).

The latent heat of vaporization of water, differential enthalpy, net isosteric heat of desorption, and Gibbs free energy are among the thermodynamic properties of the product. These thermodynamic properties have been extensively studied in the literature due to their importance for different plant products, such as cassava (Koua et al., 2014), Barbados nut (Chaves et al., 2015) seeds, castorbean seeds (Goneli et al., 2016), crambe fruits (Oliveira et al., 2017), and baru (Dipteryx alata Vogel) fruits (Resende et al., 2017).

Due to the importance of the post-harvest processes of plant products for their preservation during storage, this work aimed to study the thermodynamic properties of tamarind seeds as a function of the equilibrium moisture content and temperature.

\footnotetext{
${ }^{1}$ Instituto Federal de Educação, Ciência e Tecnologia Goiano - Campus Rio Verde/ Rio Verde - GO, Brasil.
} 


\section{MATERIAL AND METHODS}

The experiment was conducted at the Laboratory of Post-harvest of Plant Products of the Federal Institute of Education, Science, and Technology Goiano (IF Goiano), located in Rio Verde, GO, Brazil. Tamarind seeds with an initial moisture content of $21.00 \pm 0.10 \%$ dry basis $(\mathrm{db})$ were used. Fruits were collected manually in the rural region of Rio Verde, GO, Brazil (17 $51^{\prime} 57^{\prime \prime} \mathrm{S}$ and $\left.50^{\circ} 50^{\prime} 05^{\prime \prime} \mathrm{W}\right)$.

Different moisture contents were obtained after cleaning the seeds. For this, they were submitted to drying in a forced-air ventilation oven at a temperature of $45^{\circ} \mathrm{C}$ and relative humidity of $20.6 \%$ until moisture contents of $17.27,15.04,14.15,12.40$, and $10.62 \pm 0.12 \% \mathrm{db}$ were reached. The moisture contents were verified by the oven method at $105 \pm 1{ }^{\circ} \mathrm{C}$ for 24 hours (Brasil, 2009).

Desorption isotherms were determined using the indirect static method, with the water activity $\left(a_{w}\right)$ determined using the equipment HygroPalm AW1. Approximately $35 \mathrm{~g}$ of seeds were used for each moisture content in triplicate. The apparatus was placed in B.O.B. regulated at temperatures of $10,20,30$, and $40{ }^{\circ} \mathrm{C}$. After reading the water activity values in the equipment, the moisture content of the samples was determined in an oven, following the methodology of Brasil (2009).

The thermodynamic properties were obtained using the Cavalcanti Mata model (1), as it presented the best fit to the experimental data of the desorption isotherms, with a coefficient of determination $\left(\mathrm{R}^{2}\right)$ of 0.9961 , relative mean error $(\mathrm{P})$ of $1.42 \%$, average error of estimate (SE) of 0.232 , calculated chi-square $\left(\chi^{2}\right)$ of 0.0540 , AIC of 2.94 , and BIC of 6.03 .

$\mathrm{Xe}=\left(\left[\ln \left(1-\mathrm{a}_{\mathrm{w}}\right)\right) /\left(-0.005527^{* *} \cdot \mathrm{T}^{0.12914^{* *}}\right)\right]^{1 / 1.831766^{* *}}$

Where:

$\mathrm{Xe}$ is the equilibrium moisture content $(\% \mathrm{db})$;

$\mathrm{a}_{\mathrm{w}}$ is the water activity, and

$\mathrm{T}$ is the temperature $\left({ }^{\circ} \mathrm{C}\right)$.

The estimated water activity was obtained from the manipulation of the Cavalcanti Mata equation, generating [eq. (2)]:

$\mathrm{a}_{\mathrm{w}}=1-\exp \left[\mathrm{Xe}^{1.831766^{* *}}\left(-0.005527^{* *} \cdot \mathrm{T}^{0.12914^{* *}}\right)\right]$

Where:

$$
\text { ** is significant at } 1 \% \text { by the t-test. }
$$

Brooker et al. (1992) proposed Equation (3), with a reference to the Clausius-Clapeyron studies, to quantify the partial vapor pressure contained in porous systems:

$$
\operatorname{Ln}(\mathrm{Pv})=\left(\frac{L}{L^{\prime}}\right) \cdot \operatorname{Ln}(\mathrm{Pvs})+\mathrm{C}
$$

Where:

Pvs is the saturation vapor pressure of free water for a given equilibrium temperature;

$\mathrm{Pv}$ is the vapor pressure of free water for a given equilibrium temperature;

$\mathrm{L}$ is the latent heat of vaporization of water of the product $\left(\mathrm{kJ} \mathrm{kg}^{-1}\right)$;
$\mathrm{L}^{\prime}$ is the latent heat of vaporization of free water at equilibrium temperature $\left(\mathrm{kJ} \mathrm{kg}^{-1}\right)$, and

$\mathrm{C}$ is the integration constant.

The saturation vapor pressure of free water was calculated using the Thétens [eq. (4)]:

$$
\text { Pvs }=0.61078 \cdot 10^{((7.5 \mathrm{~T}) /(273.3+\mathrm{T}))}
$$

The vapor pressure value was determined according to [eq. (5)]:

$$
\mathrm{Pv}=\mathrm{a}_{\mathrm{w}} \cdot \mathrm{Pvs}
$$

The desorption isotherm allowed determining the $\mathrm{L} / \mathrm{L}^{\prime}$ ratio of [eq. (6)], according to the methodology described by Pereira \& Queiroz (1987) for different equilibrium moisture contents (Xe). Thus, the equation for enthalpy of vaporization of water, presented by RodriguesArias (Brooker et al., 1992), was adjusted with the inclusion of one more parameter in [eq. (6)] to improve the $\mathrm{L} / \mathrm{L}^{\prime}$ estimates (Corrêa et al., 1998):

$$
\left(\frac{\mathrm{L}}{\mathrm{L}^{\prime}}\right)-1=\mathrm{a} \cdot \exp \left(-\mathrm{b} \cdot \mathrm{Xe}^{\mathrm{m}}\right)
$$

Where:

$\mathrm{a}, \mathrm{b}$, and $\mathrm{m}$ are parameters determined by regression.

The latent heat of vaporization of free water $\left(\mathrm{kJ} \mathrm{kg}^{-1}\right)$ at equilibrium temperature $\left({ }^{\circ} \mathrm{C}\right)$ was calculated using the average temperature $\left({ }^{\circ} \mathrm{C}\right)$ within the range under study, using [eq. (7)]:

$$
\mathrm{L}^{\prime}=2502.2-2.39 \mathrm{~T}
$$

The latent heat of vaporization of water of the product $\left(\mathrm{kJ} \mathrm{kg}^{-1}\right)$ was estimated by combining eqs (6) and (7) (Corrêa et al., 1998), as shown in [eq. (8)]:

$$
\mathrm{L}=(2502.2-2.39 \mathrm{~T}) \cdot\left[1+\mathrm{a} \cdot \exp \left(-\mathrm{b} \cdot \mathrm{Xe}^{\mathrm{m}}\right)\right](8)
$$

The Clausius-Clapeyron equation (9) (Iglesias \& Chirife, 1976) was used to calculate the differential enthalpy for each equilibrium moisture content:

$$
\frac{\partial \ln \left(\mathrm{a}_{\mathrm{w}}\right)}{\partial \mathrm{T}}=\frac{\Delta \mathrm{h}_{\mathrm{st}}}{\mathrm{RT}_{\mathrm{abs}}^{2}}
$$

Where:

$\mathrm{T}_{\mathrm{abs}}$ is the absolute temperature $(\mathrm{K})$;

$\Delta \mathrm{h}_{\mathrm{st}}$ is the differential enthalpy $\left(\mathrm{kJ} \mathrm{kg}^{-1}\right)$, and

$\mathrm{R}$ is the universal gas constant for water vapor $\left(0.4619 \mathrm{~kJ} \mathrm{~kg}^{-1} \mathrm{~K}^{-1}\right)$.

Integrating [eq. (9)] and assuming that the differential enthalpy is independent of the temperature, each equilibrium moisture content was obtained from [eq. (10)] (Wang \& Brennan, 1991):

$$
\ln \left(\mathrm{a}_{\mathrm{w}}\right)=-\left(\frac{\Delta \mathrm{h}_{\mathrm{st}}}{\mathrm{R}}\right) \cdot \frac{1}{\mathrm{~T}_{\mathrm{abs}}}+\mathrm{C}
$$

Where:

$\mathrm{C}$ is the model coefficient. 
Net isosteric heat of sorption was obtained by adding the value of latent heat of vaporization of free water $\left(\mathrm{L}^{\prime}\right)$ to the values of differential enthalpy, according to [eq. (11)]:

$$
\mathrm{Q}_{\mathrm{st}}=\Delta \mathrm{h}_{\mathrm{st}}+\mathrm{L}^{\prime}=\mathrm{a} \cdot \exp (-\mathrm{b} \cdot \mathrm{Xe})+\mathrm{c}
$$

Where:

$\mathrm{Q}_{\mathrm{st}}$ is the net isosteric heat of sorption $\left(\mathrm{kJ} \mathrm{kg}^{-1}\right)$, and $\mathrm{a}, \mathrm{b}$, and $\mathrm{c}$ are the model coefficients.

Gibbs free energy can be calculated by [eq. (12)]:

$$
\mathrm{G}=\mathrm{R} \cdot \mathrm{T} \cdot \ln \left(\mathrm{a}_{\mathrm{w}}\right)
$$

Where:

$\mathrm{G}$ is the Gibbs free energy $\left(\mathrm{kJ} \mathrm{kg}^{-1}\right)$.

Gibbs free energy for each temperature can be described by the exponential regression shown in [eq. (13)], according to Resende et al. (2017):

$$
\mathrm{G}=\alpha \cdot \exp (\beta-\mathrm{Xe})+\delta
$$

Where:

$\alpha, \beta$, and $\delta$ are equation regression parameters.

The significance of the regression parameters was performed by the t-test to verify the degree of adjustment of each model, the magnitude of the coefficient of determination $\left(\mathrm{R}^{2}\right)$, and the relative mean error $(\mathrm{P})$, calculated according to [eq. (14)]:

$$
\mathrm{P}=\frac{100}{\mathrm{n}} \sum \frac{|\mathrm{Y}-\hat{\mathrm{Y}}|}{\mathrm{Y}}
$$

Where:

$\mathrm{Y}$ is the experimental value;

$\hat{Y}$ is the value estimated by the model, and

$\mathrm{n}$ is the number of experimental observations.

\section{RESULTS AND DISCUSSION}

Table 1 shows the water activity values estimated by the Cavalcanti Mata model for the moisture content range from 10.52 to $21.10 \% \mathrm{db}$ at temperatures of $10,20,30$, and $40{ }^{\circ} \mathrm{C}$. The water activity increases in response to an increase in temperature and moisture content. The same trend was observed by Resende et al. (2017) studying the thermodynamic properties of baru (Dipteryx alata Vogel) fruits from sorption isotherms at temperatures of 20, 25, 30, and $35{ }^{\circ} \mathrm{C}$ with an equilibrium moisture content range from 4.2 to $29.5 \% \mathrm{db}$.
TABLE 1. Water activity values (decimal) of tamarind (Tamarindus indica L.) seeds estimated by the Cavalcanti Mata model as a function of temperature and equilibrium moisture content.

\begin{tabular}{ccccc}
\hline \multirow{2}{*}{$\begin{array}{c}\text { Temperature } \\
{ }^{\circ} \mathrm{C} \\
(\% \mathrm{db})\end{array}$} & 10 & 20 & 30 & 40 \\
\cline { 2 - 5 } 10.52 & 0.4253 & 0.4544 & 0.4719 & 0.4845 \\
10.74 & 0.4375 & 0.4670 & 0.4848 & 0.4975 \\
12.39 & 0.5267 & 0.5587 & 0.5777 & 0.5912 \\
12.49 & 0.5320 & 0.5641 & 0.5831 & 0.5967 \\
14.15 & 0.6150 & 0.6480 & 0.6672 & 0.6807 \\
15.04 & 0.6560 & 0.6887 & 0.7076 & 0.7209 \\
17.27 & 0.7468 & 0.7774 & 0.7946 & 0.8066 \\
20.94 & 0.8585 & 0.8822 & 0.8950 & 0.9036 \\
21.10 & 0.8624 & 0.8857 & 0.8983 & 0.9067 \\
\hline
\end{tabular}

Table 2 shows the $L / L^{\prime}$ ratio values for different equilibrium contents. The values decrease as the moisture content increases.

TABLE 2. Values of the $\mathrm{L} / \mathrm{L}^{\prime}$ ratio for different equilibrium moisture contents of tamarind (Tamarindus indica L.) seeds

\begin{tabular}{cccc}
\hline $\begin{array}{c}\text { Moisture content } \\
(\% \mathrm{db})\end{array}$ & $\begin{array}{c}\mathrm{L} / \mathrm{L}^{\prime} \\
\text { ratio }\end{array}$ & $\begin{array}{c}\text { Moisture content } \\
(\% \mathrm{db})\end{array}$ & $\begin{array}{c}\mathrm{L} / \mathrm{L}^{\prime} \\
\text { ratio }\end{array}$ \\
\hline 10.52 & 1.0721 & 15.04 & 1.0523 \\
10.74 & 1.0712 & 17.27 & 1.0426 \\
12.39 & 1.0640 & 20.94 & 1.0283 \\
12.49 & 1.0636 & 21.10 & 1.0277 \\
14.15 & 1.0562 & & \\
\hline
\end{tabular}

Table 2 shows that the values of the $\mathrm{L} / \mathrm{L}^{\prime}$ ratio tend to be close to 1.0. This response is due to an increase in vapor pressure as moisture contents increase. Oliveira et al. (2014a) observed a similar trend for the different equilibrium moisture content of Barbados nut seeds.

The linear regression equation proposed by Corrêa et al. (1998) can be used to estimate the latent heat of vaporization of tamarind seeds. It has a high coefficient of determination $\left(\mathrm{R}^{2}\right)$, a low relative mean error $(\mathrm{P})$, and significant parameters at $1 \%$ by the t-test. Figure 1 shows the latent heat curves of vaporization of water of tamarind seeds at temperatures of $10,20,30$, and $40{ }^{\circ} \mathrm{C}$ within the equilibrium moisture content range of 10.52 to $21.10 \% \mathrm{db}$. 


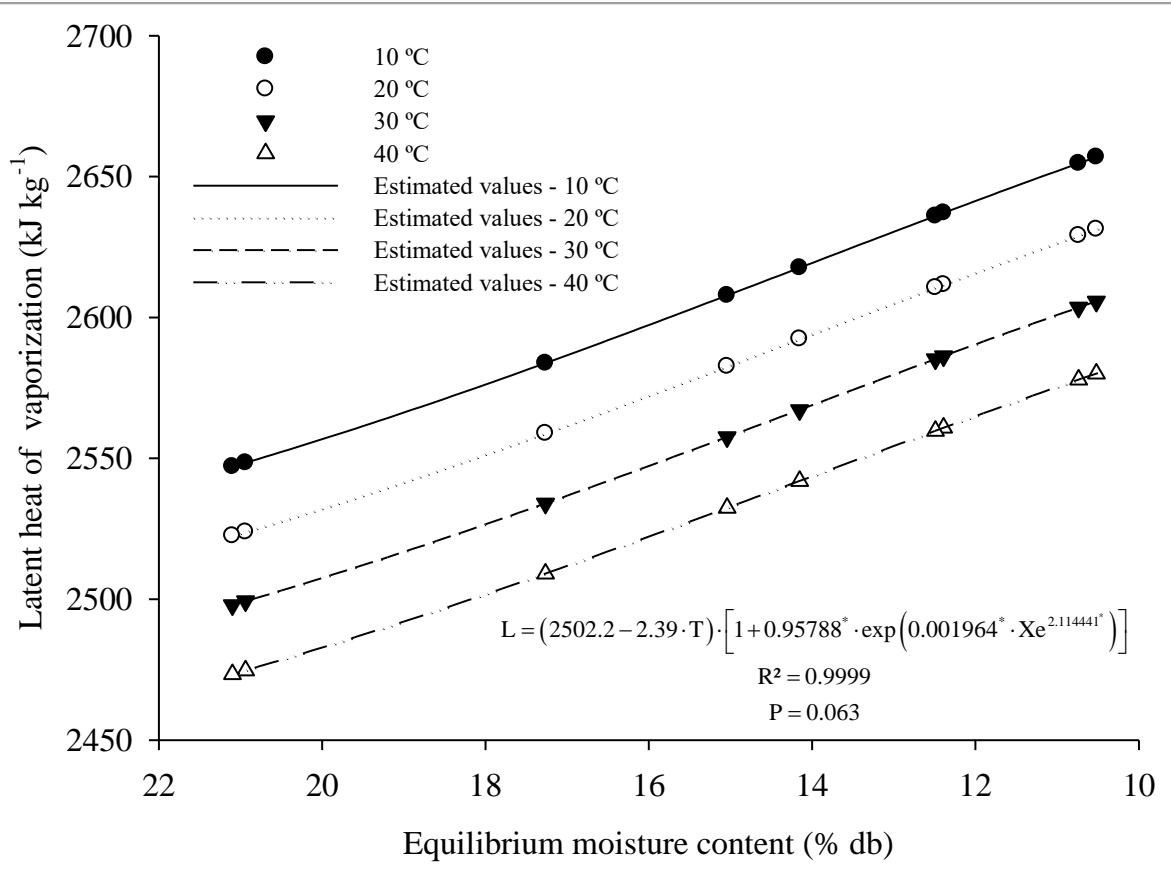

${ }^{* * *}$ Significant at $1 \%$ by the t-test.

FIGURE 1. Latent heat of vaporization of water of tamarind (Tamarindus indica L.) seeds as a function of the equilibrium moisture content for temperatures of $10,20,30$, and $40{ }^{\circ} \mathrm{C}$.

The latent heat of vaporization of water of tamarind seeds ranged from $2,656.90$ to $2,473.34 \mathrm{~kJ} \mathrm{~kg}^{-1}$. The decrease in the equilibrium moisture content leads to an increase in the energy required for water evaporation from seeds. According to Brooker et al. (1992), moisture content and temperature are the main factors influencing the latent heat of vaporization of water of the product.

The latent heat of vaporization of water of tamarind seeds decreases with increasing temperature for the same moisture content, presenting an inversely proportional relationship and corroborating with results obtained by Oliveira et al. (2017).

The latent heat value of vaporization of water of cayenne pepper (Capsicum frutescens L.) seeds ranged from
$3,615.01$ to $2,455.14 \mathrm{~kJ} \mathrm{~kg}^{-1}$ in the study conducted by Silva $\&$ Rodovalho (2016) at the moisture content range of 4.6 to $21.3 \% \mathrm{db}$ and temperatures of 30,40 , and $50{ }^{\circ} \mathrm{C}$. The latent heat of vaporization of Barbados nut seeds was 2,762.92 to $2,495.56 \mathrm{~kJ} \mathrm{~kg}^{-1}$ within the equilibrium moisture content range of 5.61 to $13.42 \% \mathrm{db}$ and at temperatures of 10,20 , 30 , and $40{ }^{\circ} \mathrm{C}$ (Oliveira et al., 2014a).

Figure 2 shows the experimental and estimated values for the differential enthalpy $\left(\Delta \mathrm{h}_{\mathrm{st}}\right)$ as a function of the different equilibrium moisture contents $(\% \mathrm{db})$ of tamarind seeds. The equation had a high coefficient of determination $\left(\mathrm{R}^{2}\right)$, low relative mean error $(\mathrm{P})$, and all equation parameters were significant at $1 \%$ by the t-test, showing the adequacy of the equation to the experimental data.

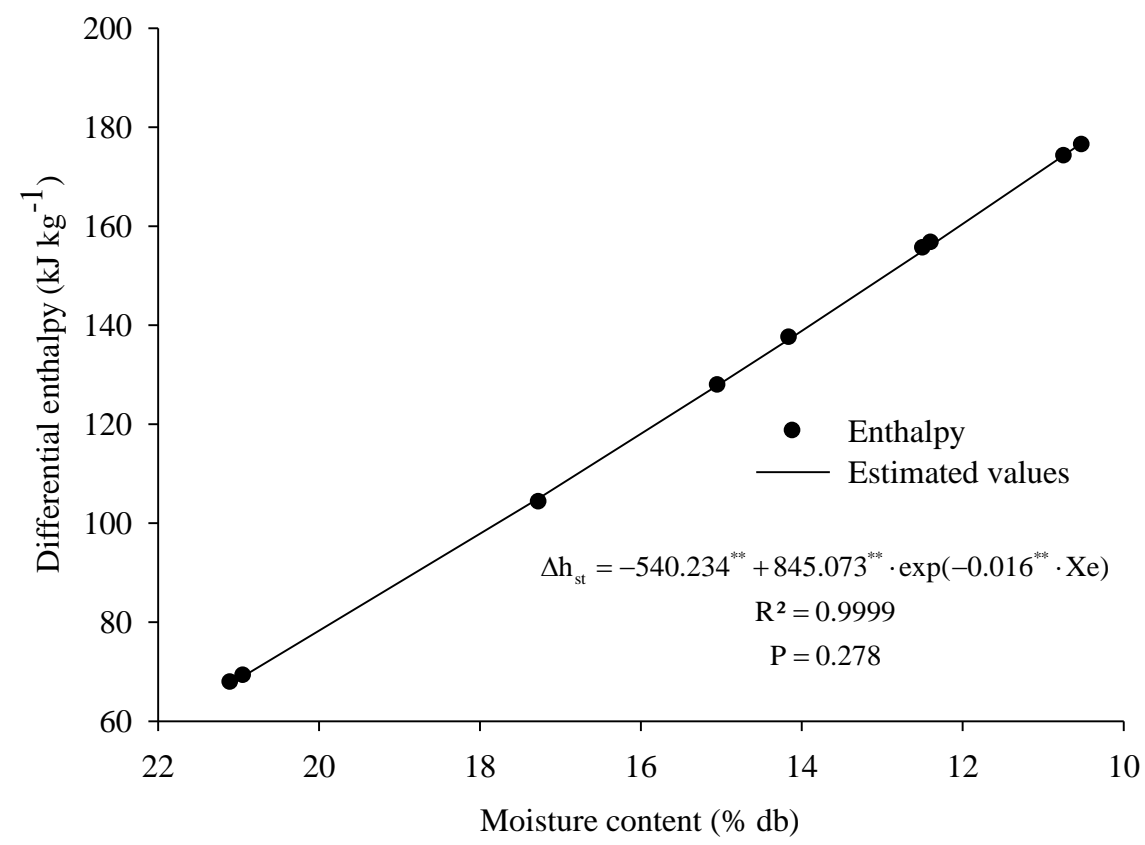

${ }^{* *}$ Significant at $1 \%$ by the t-test.

FIGURE 2. Observed and estimated values of differential enthalpy $\left(\Delta \mathrm{h}_{\mathrm{st}}\right)$ of desorption of tamarind (Tamarindus indica L.) seeds. 
Differential enthalpy increased with a reduction in moisture content (Figure 2), corroborating with the results obtained for cocoa (Theobroma cacao) seeds (Oliveira et al., 2011) and tucumã-de-Goiás (Astrocaryum huaimi Mart.) seeds (Oliveira et al., 2014b). In addition, the differential enthalpy value varied from 176.40 to $67.80 \mathrm{~kJ}$ $\mathrm{kg}^{-1}$ for a moisture content range of 10.52 to $21.10 \% \mathrm{db}$. The variation in enthalpy values provides a measure of the energy variation required to remove water when its molecules interact with constituents of the product during the sorption processes (McMinn et al., 2005).

The values of the net isosteric heat of desorption as a function of the equilibrium moisture content for tamarind seeds were calculated according to Equation (11) and shown in Figure 3. The $\mathrm{Q}_{\mathrm{st}}$ adjustment equation presented a high coefficient of determination $\left(\mathrm{R}^{2}\right)$, low relative mean error (P), and significant parameters at $1 \%$ by the t-test, which can be used to estimate the net isosteric heat of desorption of tamarind seeds.

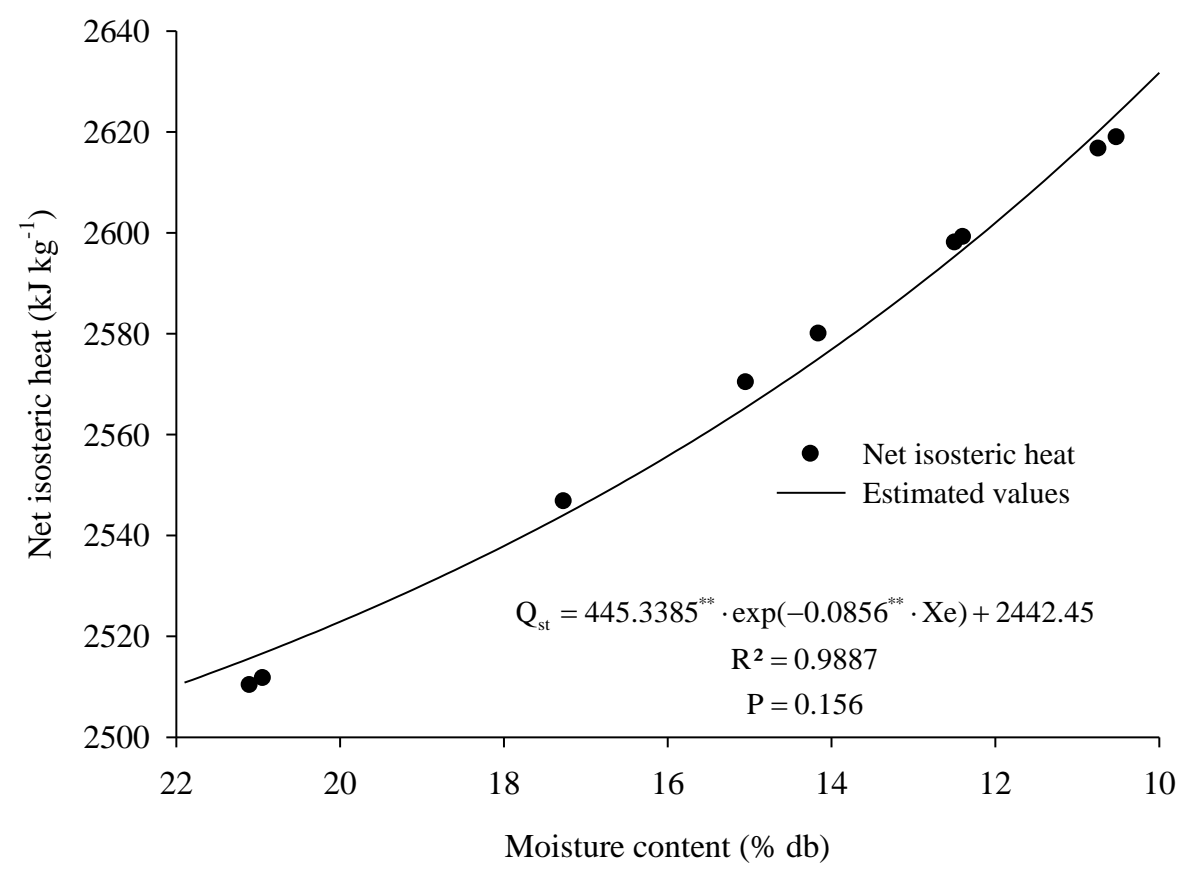

${ }^{* *}$ Significant at $1 \%$ by the t-test.

FIGURE 3. Experimental and estimated values of the net isosteric heat of desorption as a function of the equilibrium moisture content of tamarind (Tamarindus indica L.) seeds.

Figure 3 shows that as the moisture content of the product decreases, more energy must be provided to remove water, corroborating with the results obtained for different plant products, such as baru (Dipteryx alata Vogel) beans (Furtado et al., 2014), forage radish (Raphanus sativus L.) seeds (Sousa et al., 2015), cajuzinho-do-cerrado (Anacardium humile A.St.-Hil.) achenes (Barbosa et al., 2016), and pequi (Caryocar brasiliense Camb.) diaspores (Sousa et al. 2016).

The values of the net isosteric heat of desorption for tamarind seeds in the equilibrium moisture content range of 10.52 to $21.10 \% \mathrm{db}$ varied from $2,618.85$ to $2,510.25 \mathrm{~kJ}$ $\mathrm{kg}^{-1}$. Seeds of fourleaf buchenavia (Buchenavia capitata (Vahl) Eichler) showed values of the net isosteric heat of desorption ranging from $2,667.93$ to $2,819.56 \mathrm{~kJ} \mathrm{~kg}^{-1}$ and equilibrium moisture contents ranging from 13.31 to $7.21 \%$ db (Costa et al., 2015). Chaves et al. (2015) studied the net isosteric heat of desorption of Bermuda nut seeds in the moisture content range of 5.6 to $13.4 \% \mathrm{db}$ and obtained values a variation of $3,035.61$ to $2,631.89 \mathrm{~kJ} \mathrm{~kg}^{-1}$.

Water-holding capacity to product constituents increases as the moisture content of the sample decreases due to an increase in the concentration of the chemical constituents of the product, such as fats, proteins, and salts (Hubinger et al., 2009). Low moisture contents indicate proximity to monomolecular layers, which are strongly linked to dry matter and require a higher energy rate to remove water in the form of steam (Al-Muhtaseb et al., 2004).

Gibbs free energy increased with decreasing moisture content and temperature, being positive for all studied conditions (Table 3). The values of this thermodynamic property tend to stabilize at higher equilibrium moisture contents. Resende et al. (2017) and Silva et al. (2016) observed similar behaviors. 
TABLE 3. Gibbs free energy values $\left(\mathrm{kJ} \mathrm{kg}^{-1}\right)$ as a function of the moisture content of tamarind (Tamarindus indica L.) seeds.

\begin{tabular}{ccccc}
\hline Moisture content $(\% \mathrm{db})$ & \multicolumn{4}{c}{ Temperature $\left({ }^{\circ} \mathrm{C}\right)$} \\
\cline { 2 - 5 } & 10 & 20 & \multicolumn{3}{c}{30} \\
\hline 10.52 & 111.81 & 106.81 & 105.17 & 104.82 \\
10.74 & 108.11 & 103.09 & 101.39 & 100.98 \\
12.39 & 83.85 & 78.83 & 76.84 & 76.01 \\
12.49 & 82.55 & 77.53 & 75.53 & 74.69 \\
14.15 & 63.57 & 58.76 & 56.67 & 55.63 \\
15.04 & 55.15 & 50.51 & 48.43 & 47.34 \\
17.27 & 38.18 & 34.10 & 32.19 & 31.09 \\
20.94 & 19.95 & 16.97 & 15.54 & 14.67 \\
21.10 & 19.36 & 16.43 & 15.02 & 14.16 \\
\hline
\end{tabular}

The positive values observed for Gibbs free energy were expected since desorption is a non-spontaneous process, characteristic of an exogenous reaction, i.e., a reaction that requires an agent supplying energy to the environment. Corrêa et al. (2015) observed positive values for the Gibbs free energy of cucumber (Cucumis sativus L.) seeds, as well as Goneli et al. (2016) for castorbean (Ricinus communis L.) seeds.

Table 4 shows the exponential regression equations for Gibbs free energy.

TABLE 4. Gibbs free energy equations of tamarind (Tamarindus indica L.) seeds for different temperatures.

\begin{tabular}{cccc}
\hline Temp. $\left({ }^{\circ} \mathrm{C}\right)$ & Equation $^{*}$ & $\mathrm{R}^{2}(\mathrm{decimal})$ & $\mathrm{P}(\%)$ \\
\hline 10 & $\mathrm{G}=539.7360^{* *} \cdot \exp \left(-0.1445^{* *} \cdot \mathrm{Xe}\right)-6,2564^{* *}$ & 0.9999 & 0.069 \\
20 & $\mathrm{G}=562.4996^{* *} \cdot \exp \left(-0.1527^{* *} \cdot \mathrm{Xe}\right)-6,0434^{* *}$ & 0.9999 & 0.126 \\
30 & $\mathrm{G}=585.0464^{* *} \cdot \exp \left(-0.1579^{* *} \cdot \mathrm{Xe}\right)-5,9386^{* *}$ & 0.9999 & 0.168 \\
40 & $\mathrm{G}=607.3941^{* *} \cdot \exp \left(-0.1618^{* *} \cdot \mathrm{Xe}\right)-5,8896^{* *}$ & 0.9999 & 0.202 \\
\hline
\end{tabular}

*Equation (13): $\mathrm{G}=\alpha \cdot \exp (\beta-\mathrm{Xe})+\delta .{ }^{* *}$ Significant at $1 \%$ by the t-test.

Equation (13), described by Resende et al. (2017), can be used to determine Gibbs free energy for the studied temperatures. The values of Gibbs free energy presented a high coefficient of determination (R2), low relative mean error $(\mathrm{P})$, and all parameters significant at $1 \%$ by the t-test under the studied conditions. Table 4 shows that the values of the regression parameters ( $\alpha$ and $\beta$ ) of [eq. (13)] increased with an increase in temperature, while the parameter $\delta$ had an opposite effect.

\section{CONCLUSIONS}

Thermodynamic properties are influenced by the moisture content of tamarind seeds, with an increase in the energy required to remove water from the product with a decrease in moisture content.

The net isosteric heat of desorption increases with a reduction in the moisture content, ranging from 2,618.85 to $2,510.25 \mathrm{~kJ} \mathrm{~kg}^{-1}$ for the moisture content range of 10.52 to $21.10 \% \mathrm{db}$.

The latent heat of vaporization, the differential enthalpy, and the Gibbs free energy increase with a reduction of the moisture content of tamarind seeds.

\section{ACKNOWLEDGEMENTS}

The authors extend thanks to IF Goiano, CAPES, FAPEG, FINEP and CNPq for their financial support, which was indispensable to the execution of this study.

\section{REFERENCES}

Al-Muhtaseb AH, McMinn WAN, Magee TRA (2004) Water sorption isotherms of starch powders. Part 2: Thermodynamic characteristics. Journal of Food Engineering 62(2):135-142. DOI: https://doi.org/10.1016/S0260-8774(03)00202-4

Barbosa KF, Sales JF, Resende O, Oliveira DEC, Zuchi J, Sousa (2016) Desorption isotherms and isosteric heat of 'cajuzinho-do-cerrado' achenes. Revista Brasileira de Engenharia Agrícola e Ambiental 20(5):481-486. DOI: http://dx.doi.org/10.1590/1807-1929/agriambi.v20n5p481-486

Brasil - Ministério da Agricultura, Pecuária e Abastecimento (2009) Regras para análise de sementes. Brasília, MAPA/ACS, 395p.

Brooker DB, Bakker-Arkema FW, Hall CW (1992) Drying and storage of grains and oilseeds. Westport, The AVI Publishing, 450p.

Cladera-Oliveira F, Pettermann AC, Noreña CPZZ, Wada $\mathrm{K}$, Marczak LDF(2008) Thermodynamic properties of moisture desorption of raw pinhão (Araucaria angustifolia seeds). International Journal of Food Science and Technology 43(3):900-907. DOI: https://doi.org/10.1111/j.1365-2621.2007.01540.x

Chaves TH, Resende O, Oliveira DEC, Smaniotto TAS, Sousa (2015) Isotermas e calor isostérico das sementes de pinhão-manso. Engenharia na Agricultura 23(1)9-18. DOI: https://doi.org/10.13083/1414-3984/reveng.v23n1p9-18 
Corrêa PC, Christ D, Martins JH, Mantovani BHM (1998) Curvas de dessorção e calor latente de vaporização para as sementes de milho pipoca. Revista Brasileira de Engenharia Agrícola e Ambiental 2(1):7-11. DOI: http://dx.doi.org/10.1590/1807-1929/agriambi.v2n1p75-79

Corrêa PC, Oliveira GHH, Botelho FM, Goneli ALD, Carvalho FM (2010) Modelagem matemática e determinação das propriedades termodinâmicas do café (Coffea arabica L.) durante o processo de secagem. Revista Ceres 57(5):595-601. DOI: http://dx.doi.org/10.1590/S0034-737X2010000500005

Corrêa PC, Reis MFT, Oliveira GHH, Oliveira APLR, Botelho FM (2015) Moisture desorption isotherms of cucumber seeds: modeling and thermodynamic properties. Journal of Seed Science 37(3):218-225. DOI: http://dx.doi.org/10.1590/2317-1545v37n3149549

Costa LM, Resende O, Oliveira DEC, Sousa (2015) Isotermas e calor isostérico de sementes de Buchenavia capitata (Vahl) Eichler. Revista Ciência Agronômica 46(3):516-523. DOI: http://dx.doi.org/10.5935/18066690.20150033

Furtado GF, Silva FS, Porto AG, Santos P (2014) Dessorção e calor isostérico de amêndoas de baru. Revista Brasileira de Tecnologia Agroindustrial 8(2):1416-1427. DOI: https://doi.org/10.3895/S1981-36862014000200010

Goneli ALD, Corrêa PC, Oliveira GHH, Oliveira APLR, Orlando RC (2016) Moisture sorption isotherms of castor beans. Part 2: Thermodynamic properties. Revista Brasileira de Engenharia Agrícola e Ambiental 20(8):757762. DOI: http://dx.doi.org/10.1590/1807-

1929/agriambi.v20n8p757-762

Hubinger MD, Vivanco-Pezantes D, Kurozawa LE, Sobral PJA (2009) Isotermas de dessorção de filé de bonito (Sarda sarda) desidrato osmoticamente e defumado. Revista Brasileira de Engenharia Agrícola e Ambiental 13(3):305-311. DOI: http://dx.doi.org/10.1590/S141543662009000300012

Iglesias H, Chirife J (1976) Prediction of the effect of temperature on water sorption isotherms of food material. Journal of Food Technology 11(2):109-116. DOI: https://doi.org/10.1111/j.1365-2621.1976.tb00707.x

Koua BK, Koffi PME, Gbaha P, Toure S (2014) Thermodynamic analysis of sorption isotherms of cassava (Manihot esculenta). Journal of Food Science Technology 51(9):1711-1723. DOI: https://doi.org/10.1007/s13197012-0687-y

McMinn WAM, Al-Muhtaseb AH, Magee TRA (2005) Enthalpy-entropy compensation in sorption phenomena of starch materials. Journal of Food Engineering 38(5):505510. DOI: https://doi.org/10.1016/j.foodres.2004.11.004

Pereira IAM, Queiroz DM (1987) Higroscopia. Viçosa, Centreinar, 28p.

Oliveira AKM, Schleder ED, Favero S (2006)

Caracterização morfológica, viabilidade e vigor de sementes de Tabebuia aurea (Silva Manso) Benth. \& Hook. f. ex. S. Moore. Revista Árvore 30(1):25-32. DOI: https://doi.org/10.1590/s0100-67622006000100004
Oliveira GHH, Corrêa PC, Santos ES, Treto PC, Diniz MDMS (2011) Evaluation of thermodynamic properties using GAB model to describe the desorption process of cocoa beans. International Journal of Food Science \& Technology 46(10):2077-2084. DOI: https://doi.org/10.1111/j.1365-2621.2011.02719.x

Oliveira DEC, Resende O, Chaves TH, Sousa KA, Smaniotto TAS (2014a) Propriedades termodinâmicas das sementes de pinhão manso. Bioscience Journal, 30(1):147-157.

Oliveira DEC, Resende O, Chaves TH, Sousa KA, Smaniotto TAS (2014b) Propriedades termodinâmicas de sementes de tucumã-de-goiás (Astrocaryum huaimi Mart.). Revista Caatinga 27(3):53-62.

Oliveira DEC, Resende O, Costa LM, Silva HW (2017)

Thermodymnamic properties of crambe fruits. Acta Scientiarum 39(3):291-298. DOI:

http://dx.doi.org/10.4025/actasciagron.v39i3.32516

Resende O, Ullmann R, Siqueira VC, Chaves TH, Ferreira LU (2011) Modelagem matemática e difusividade efetiva das sementes de pinhão-manso (Jatropha curcas L.) durante a secagem. Engenharia Agrícola 31(6):1123-1135. DOI: http://dx.doi.org/10.1590/S010069162011000600010

Resende O, Oliveira DEC, Costa LM, Ferreira Junior WN (2017) Thermodynamic properties of baru fruits (Dipteryx alata Vogel). Engenharia Agrícola 37(4):39-749. DOI: http://dx.doi.org/10.1590/1809-4430eng.agric.v37n4p739-749/2017

Silva HW, Rodovalho RS (2016) Adsorption isotherms and vaporization latente heat of malagueta pepper seeds. Científica 44(1):5-13. DOI: http://dx.doi.org/10.15361/1984-5529.2016v44n1p5-13

Silva HW, Costa LM, Resende O, Oliveira DEC, Soares RS, Vale LSR (2016) Thermodynamic properties of pepper seeds - variety 'Cabacinha'. Científica 44(1):1422. DOI: http://dx.doi.org/10.15361/19845529.2016v44n1p14-22

Sousa DMM, Bruno RLA, Dornelas CSM, Alves EU, Andrade AP, Nascimento LC (2010) Caracterização morfológica de frutos e sementes e desenvolvimento pósseminal de Tamarindus indica L. - Leguminosae: caesalpinioideae. Revista Árvore 34(6):1009-1015. DOI: http://dx.doi.org/10.1590/S0100-67622010000600006

Sousa KA, Resende O, Goneli ALD, Smaniotto TAS, Oliveira DEC (2015) Thermodynamic properties of water desorption of fodder radish seeds. Acta Scientiarum. Agronomy 37(1):11-19. DOI:

http://dx.doi.org/10.4025/actasciagron.v37i1.19333

Sousa Ka, Resende O, Carvalho BS (2016) Determination of desorption isotherms, latent heat and isosteric heat of pequi diaspore. Revista Brasileira de Engenharia Agrícola e Ambiental 20(5):493-498. DOI: http://dx.doi.org/10.1590/1807-1929/agriambi.v20n5p493-498

Wang N, Brennan JG (1991) Moisture sorption isotherm characteristics of potato at four temperatures. Journal of Food Engineering 14(4):269-287. DOI: https://doi.org/10.1016/0260-8774(91)90018-N 